\title{
The Way of Floating Peat Formation in Karst Depressions of European Russia
}

\author{
E.M. Volkova*
}

Botany Department, Tula State Pedagogical University, pr. Lenina, 125, Tula, 300026, Russia

\begin{abstract}
Deep karst depressions with a large volume of water due to a poor water drainage system (caused by a clay layer, etc.) and with steeply sloping sidewalls paludificate in a special way. Peat formation begins with dead vegetative material (leaves, etc.) floating on the water's surface in the center of the karst lake. The peat grows laterally from the center of the depression to its edges and the thickness of the peat also increases. However, since the peat is floating, it normally has a thickness of only 2-3 meters, because the lower layer of the peat usually breaks off and sinks down to the bottom of the lake. During this time, the vegetation may change from eutrophic to meso- and oligotrophic types.
\end{abstract}

Keywords: Karst depressions peat, floating peat formation, European Russia.

\section{INTRODUCTION}

The formation of floating peat has been described in many places of the world. In some cases the peat forms as a result of masses of vegetation that tear from the shore or from lake bottoms, which is possible if water levels begin to be higher through natural means (hydrological features of area) or by anthropogenic activity (for example, the building of a dam). In other cases floating peat formation is typical for stagnant waters and correlates with the formation of floating plant communities (Salvinia ariculata, Pistia stratiotes, Chorisandra cymbaria, others) which are colonized later by various plants (including woody ones) [16]. Therefore, the path of peat mat formation goes in two directions: "bottom up or top down" [7].

The origin of such lakes with floating mats is different. In mountains, on hills, and along coasts glacial depressions (kettle holes) form very often [8-14]. On territories with limestone or gypsum in Carboniferous and Devonian bedrock karst depressions are typical [15].

In European Russia the intensity of karst formation is high, especially in the zone of deciduous forest, because decomposition of fallen leaves increases surface and ground water acidity and dissolution of limestone/gypsum in bedrock occurs faster. In this case, dissolution results in a cavern with a bedrock roof which eventually collapses to form a sinkhole. Usually such karst depressions on the surface are comparatively deep (up to 10 meters or more, as measured from the top of the depression's rim to the deepest part of its surface floor) and have a round or elliptical surface shape.

Karst sinkholes may remain dry if they have drainage holes. Some depressions have clay on their floors and therefore do not have good drainage systems. For this reason, karst sinkholes can retain water and convert to lakes or mires.

*Address correspondence to this author at the Botany Department, Tula State Pedagogical University, pr. Lenina, 125, Tula, 300026, Russia; Tel: +7(4872)35-78-08; Fax: +7(4872)35-40-60; E-mail: convallaria@mail.ru
The paludification of karst depressions depends on the presence of a relatively waterproof layer of clay on the floor of the depression (which prevents or greatly reduces downward drainage of water) and on the lack of a good lateral drainage system as well. For these reasons the depressions may retain ground and surface waters. The volume of water may vary because some of the water evaporates, some drains along the surface, and some even moves down to the ground water. Therefore, karst depressions may contain different volumes of water and may paludificate by several ways - "bottom down or top up?". The analyses of peat stratigraphy of karst-hole mires have allowed the determination of these ways more carefully.

The main first way is characterized by peat formation on the surface of the sinkhole floor. This is possible if the depression has only small surface areas of shallow water (small ponds). This provides conditions for the growth of trees (willow, birch) and the formation of woody peat on the surface of the depression floor. These mires are characterized by euthrophic vegetation and a depth of peat deposits of less than 1 meter [16].

Deeper karst depressions (5-9 meters) with high and steeply sloping side walls and a small amount of water paludificate in another way because the shallow water has only a small surface area. Peat formation begins on the surface of the depression's floor from the green mosses community (Drepanocladus sp., Calliergon cordifolium). Later, other plants (herbs, trees) begin to grow on the greenmosses-peat, which allows the accumulation and vertical grows of peat. The vegetation is also of the euthrophic type $[17,18]$.

Thus in these cases mires have full peat deposits, which grow from the bottom of the depressions to the surface, i.e., the "bottom up" method of paludification.

The second main way - with float formation on the water surface - is characterized by deep karst depressions (10-15 meters) with a large amount of water (karst ponds or lakes). The origin of floats may be different. One path is typical for ponds with shallow water and is characterized by the 
formation of sedge (or other rhizomatous herbs) communities on the bottom of the depression. Rhizomes of plants form the mat, which can easily tear from the bottom, especially by rising water level. As a result, the mat floats on the water surface and has no connections with the mineral bottom of the depression. Mosses and vascular plants invade the mat later and allow the peat to grow vertically. A second path has a specific feature - just the top layer of peat tears and rises to the surface after water fills up the depression. It means that such mires have two parts of their peat deposits: the floating peat on the water surface and the layer of peat lying on the bottom of the pond/lake. Floating peat can be invaded by different plants, which allows for peat growth [18]. It is important to mention that the float uses mostly atmospheric waters (root layer) and the succession of vegetation to the oligothrophic stage goes faster.

Thus, float can form in this different direction - by "top down", which means that float formation begins on the water surface. To investigate this idea, research of several karst mires in the Tula region was conducted.

\section{MATERIALS AND METHODOLOGY}

The area of research is the Tula region which is located in the center of the Russian Plain, between the heads of the rivers Don and Oka, on the boundary of the coniferousdeciduous forest, deciduous forest, and forest-steppe vegetation zones. The total surface area of all types of mires is 1600 ha, which is $0.07 \%$ of the land $[16,19]$. Karst mires are present in different parts of the region, but they are more typical in the deciduous forest vegetation zone. All together, karst mires comprise more than $35 \%$ of the total number of all mires, but their total surface area is a small - about $4 \%$ of the total surface area of all mires. Float karst mires are more rare than mires with full peat deposits.

The structure of the peat deposit of several mires near Ozerniy village and the mire Lipki were analyzed to understand the stages of float formation. For each mire the vegetation was described, the depth of the peat deposits were measured, and peat samples were collected from the deepest point for microfossil analysis [20]. All this information and analyses were used to reconstruct the history of paludification for each mire.

\section{RESULTS}

Field and lab work produced data on the vegetation and peats for each float karst mire, which allowed the stages of their development to be determined.

Mire Voronka (Ozerniy village) is a karst depression (depth $7 \mathrm{~m}$, area $0.05 \mathrm{ha}$ ) in the first stage of paludification. A vegetative float comprised of fallen leaves from trees of the surrounding area has a depth of $40 \mathrm{~cm}$, and it floats on the water's surface. This float has remains of ferns, horsetails, some grasses, Calla palustris, and green mosses. The first true peat deposit is herbal-green mosses (Fig. 1A). The vegetation is Athyrium filix-femina+Impatiens nolitangere.

Mire Chernool'shanik (Ozerniy village) shows the next stages in development of float. The depth of karst depression is more than $7 \mathrm{~m}$, and the area of mire is 0.07 ha. Vegetation of the central part is the communities Alnus glutinosa-
Athyrium filix-femina+Thelypteris palustris and Alnus glutinosa-Calla palustris.

The peat deposit is a float $1.5 \mathrm{~m}$ thick, formed by herbalsphagnum and herbal eutrophic peat with large amount of fallen leaves. Broken off parts of float peat were observed under the float at a depth of 5-6.5 m (Fig. 1B). These broken off parts included the remains of fallen leaves.

Lubimoe mire (Ozerniy village) has an area of 0.18 ha and forms in a karst depression $7 \mathrm{~m}$ deep. This depression is actually a series of separate but interconnected depressions filled by surface water. The vegetation of the central part of the modern float is the Betula pubescens-Menyanthes trifoliata-Sphagnum centrale community.

Vegetation grows on the float, which is $2.0 \mathrm{~m}$ thick (Fig. 1C). The float was formed by herbal (sometimes with trees remains) and herbal-sphagnum eutrophic peats (with Menyanthes trifoliata, Calla palustris, Scirpus sylvaticus, Calamagrostis sp., Phragmites austalis, Comarum palustre, Epilobium sp., Carex cespitosa, Equisetum sp., Polytrichum sp., and Sphagnum centale). Broken off pieces of float were found below the float at a depth of 6.5-6.6 $\mathrm{m}$ (sphagnum eutrophic peat) and $6.6-6.7 \mathrm{~m}, 6.9-7.0 \mathrm{~m}$ (Bryales peat). Also, fallen leaves (with low degree of decomposition) were found in these separated parts of float.

Mire Lipki has 0.3 ha and is located in a very deep depression (more than $12 \mathrm{~m}$ ). The living vegetation grows on float and is of several different communities. Betula pubescens-Menyanthes trifoliata-Sphagnum riparium, Salix cinerea-Menyanthes trifoliata+Comarum palustre-Sphagnum teres, Salix cinerea-Calla palustris-Calliergon cordifolium, Menyanthes trifoliata+Comarum palustre-Sphagnum squarrosum and Carex rostrata + Comarum palustre-Sphagnum teres are all near the edge of the float.

The central part of the float has hummocks with wide flat areas (carpets) between them. The hummocks have the Eriophorum polystachion-Sphagnum magellanicum community. Between them on the carpets are the communities Carex rostrata + C. lasiocarpa-Sphagnum angustifolium + S. fallax and Rhynchospora alba+Carex rostrata-Sphagnum magellanicum + $\mathrm{S}$. angustifolium (more oligotrophic conditions).

The float $(2.5 \mathrm{~m})$ has sphagnum, cottongrass-sphagnum, and herbal-sphagnum mesotrophic peats and wood-herbal eutrophic peat (Fig. 1D). The lowest part of the float is wood-herbal eutrophic peat. Under the float $(5 \mathrm{~m})$, a separate layer of broken off pieces of herbal-sphagnum peat (with Menyanthes trifoliata) was found.

The same large karst depression near Ozerniy village contained mire Bol'shoye, which was also paludificated by float formation. The communities near the edges are Betula pubescens-Carex acuta, Betula pubescens-Carex vesicaria, Betula pubescens-Scirpus sylvaticus, Betula pubescensCalamagrostis neglecta -Calliergon cordifolium. The central part of the mire is of the Eriophorum vaginatum - Sphagnum magellanucum $+\mathrm{S}$. angustifolium community, which is formed on the float (1.5 m thick) and has cottongrasssphagnum mesotrophic peat (Fig. 1E). Under the float (8.5$9.0 \mathrm{~m}$ ), separate broken off pieces of float (cottongrasssphagnum peat also) were found. 


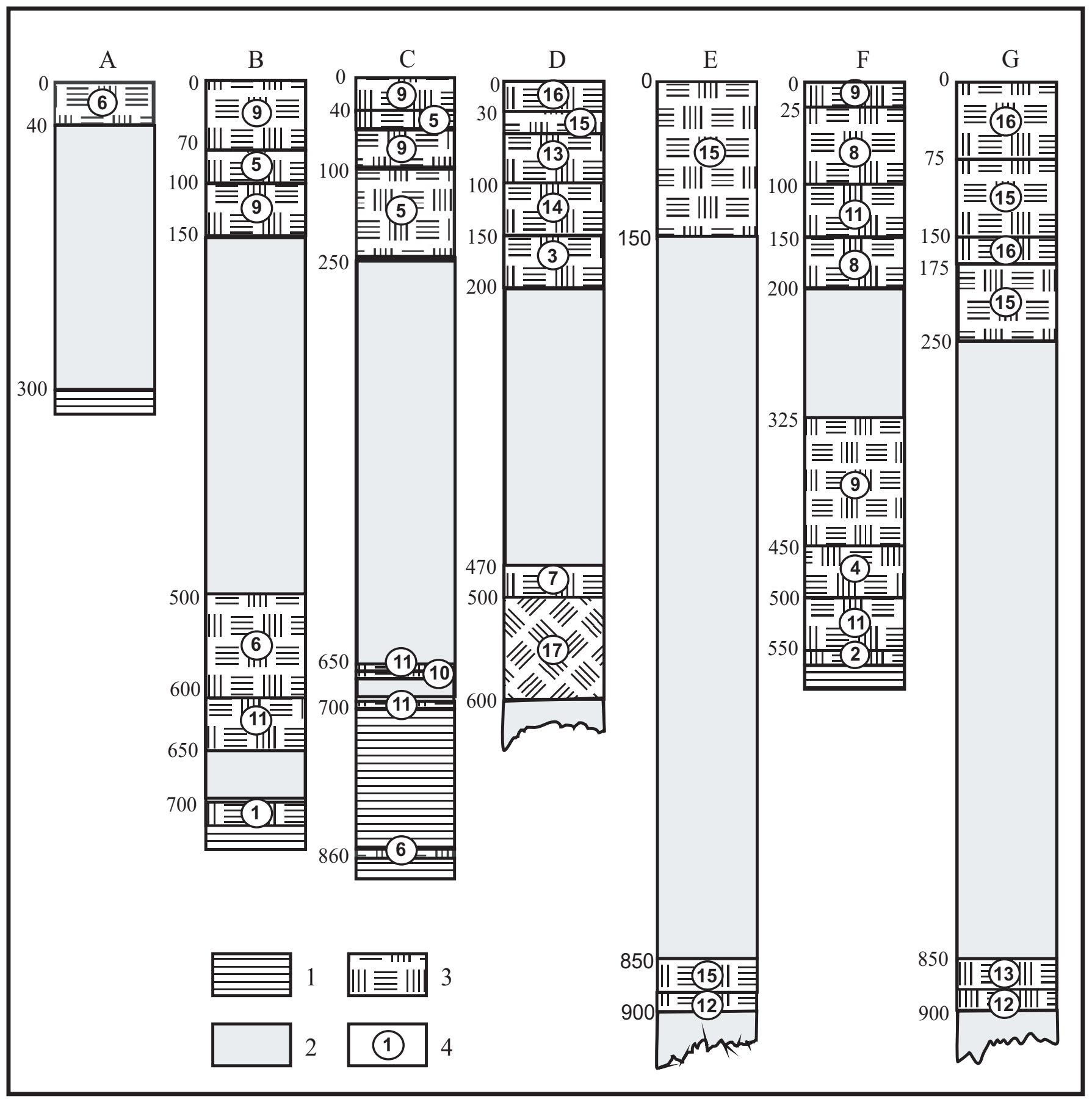

Fig. (1). Peat profiles of floating mires: A - mire Voronka (Ozerniy village), B - mire Chernool'shanik (Ozerniy v.), C - Lubimoe mire (Ozerniy v.), D - mire Lipki (Lipki v.), E - mire Bol'shoe (Ozerniy v.), F - edge of mire Glavnoye (Ozerniy v.), G - center of mire Glavnoye (Ozerniy v.). Eutrophic peats: $\mathbf{1}$ - wood, $\mathbf{2}$ - wood-sedge, $\mathbf{3}$ - wood-herbal, $\mathbf{4}$ - buck bean, $\mathbf{5}$ - herbs, $\mathbf{6}$ - herbal-hypnum, $\mathbf{7}$ - buck bean-sphagnum, 8 - sedge-sphagnum, 9 - herbal-sphagnum, 10 - hypnum (brown mosses), 11 - sphagnum; Mesotrophic peats: 12 cottongrass, 13 - herbal-sphagnum, 14 - sedge-sphagnum, 15 - cottongrass-sphagnum, 16 - sphagnum; 17 - peat remains, 18 - water, 19 clay. 
Mire Glavnoye was paludificate by other way. The mire (area more than $1 \mathrm{ha}$ ) arises in a huge linear depression (depth more $12 \mathrm{~m}$ ) which is a series of small and separate but interconnected depressions filled by surface water (Fig. 3). The edges of the mire are characterized by the eutrophic communities Scirpus sylvaticus-Calla palustris, Salix cinerea-Scirpus sylvaticus, Betula pubescens-Carex acutiformis, Betula pubescens-Thelypteris palustris, Betula pubescens-Menyanthes trifoliata-Sphagnum riparium. At the edges the thickness of the peat deposit is 4-6 m. The edge deposit may be complete from bottom to top (non-floating), or it may be floating with broken off pieces underneath. In the latter case, vegetation grows on the float ( $2 \mathrm{~m}$ thick), which is herbal-sphagnum and sedge-sphagnum eutrophic peats (Figs. 1F, 3). Under the float is a layer of water $(2.0-$ $3.2 \mathrm{~m})$, which covers peat that was formed on the depression's floor. This part of the peat deposit at the edges has herbal-sphagnum $(3.2-5.0 \mathrm{~m})$, sphagnum $(5.0-5.5 \mathrm{~m})$ and wood-sedge (5.5-5.6 m) eutrophic peats.

Mesotrophic vegetation of the mire is a carpet with rare hummocks. Vegetation of the carpets is of the Rhynchospora alba-Carex rostrata-Sphagnum magellanicum + S.fallax and Rhynchospora alba-Carex rostrata-Sphagnum fallax $+\mathrm{S}$. angustifolium communities. Sphagnum magellanicum and $S$. angustifolium grow on the hummocks, as do young trees of Betula pubescens (height 3-4 m) and Oxycoccus palustris. Between the mesotrophic center and the eutrophic edge, the Betula pubescens-Carex lasiocarpa $+C$. rostrata-Sphagnum fallax community is present. This vegetation is typical for the central part and is characteristic for float $(2.5-3.0 \mathrm{~m}$ thick). Cottongrass-sphagnum and sphagnum mesotrophic kinds of peat form this float. Broken off parts of the float were found to a depth of 8-9 $\mathrm{m}$. They are formed by herbalsphagnum and cottongrass peats (Figs. 1G, 3 ).

\section{DISCUSSION}

Mire Voronka. The substrate from leaves and first peat remains is the base for the modern vegetation. The living vegetation produces a vertical growth of the peat deposit. Therefore, the first stage of floating peat formation is from fallen leaves. The level of the float rises and falls as the water level in the depression rises or falls (seasonal fluctuation) [21].

Mire Chernool'shanik. Paludification of the karst depression evidently began after it filled up with water and occurred by the formation of a float from fallen leaves on the water's surface. On top of these floating leaves, herbs and green and sphagnum mosses began to grow, which is stage two. Nutrient-rich surface water probably was the reason for the long term existence of the second stage eutrophic herbalsphagnum communities, apparent from the thickness of the stratum. Increasing float thickness provided conditions for the growth of trees (birch, black alder), which leads to the third stage in float development - the stage of the forest (trees) mire.

Lubimoe mire. Paludification began from the float which originally started to grow from leaf float. The floating leaves were inhabited by green mosses at first, but later Sphagnum mosses and herbs invaded. Therefore, paludification of the depression is similar as in the previous mire except that there is a new, fourth stage of float development: domination of
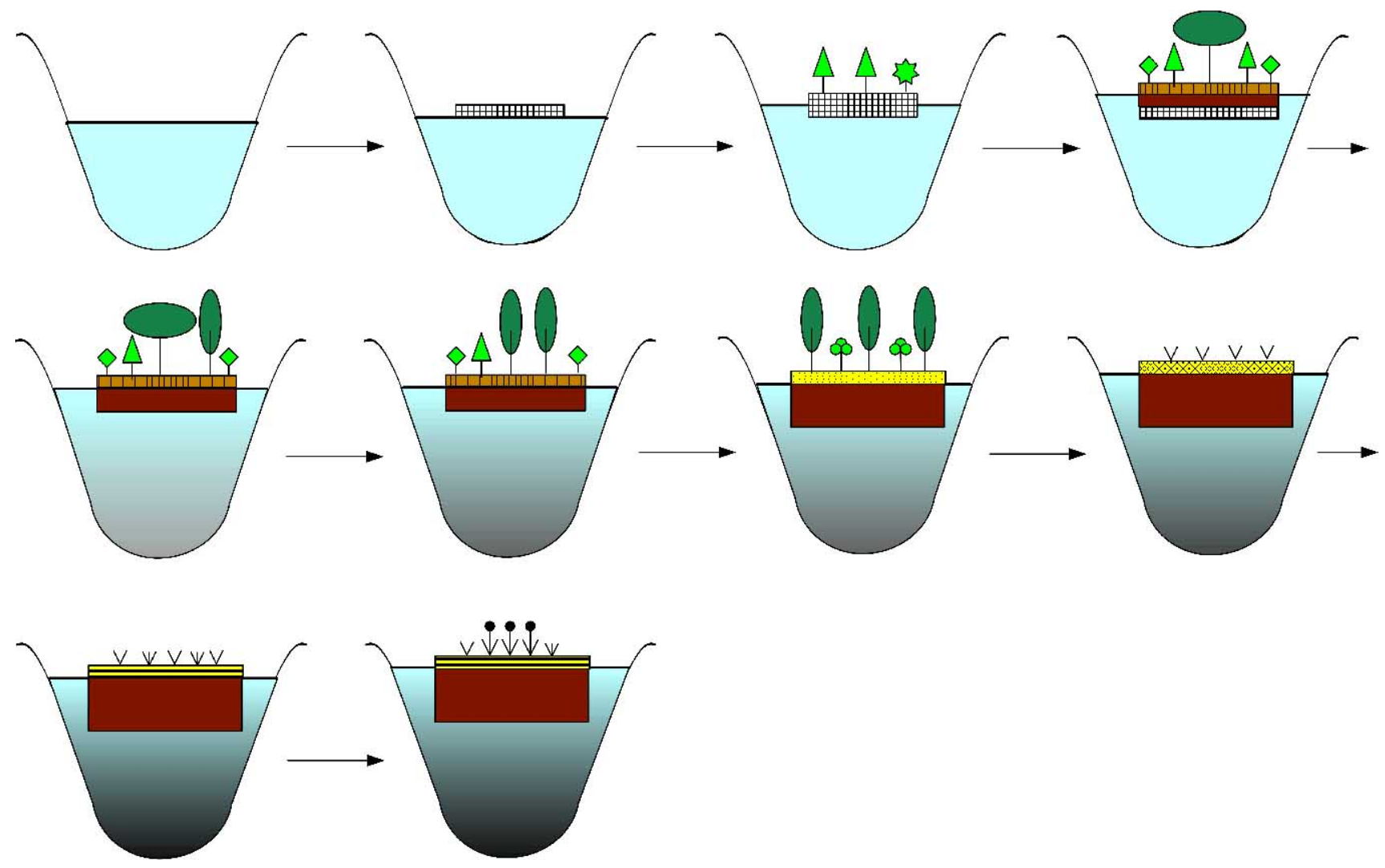

Fig. (2). Paludification of deep karst depressions with high and steeply sloping side walls and a large amount of water (the explanations - see the text). 

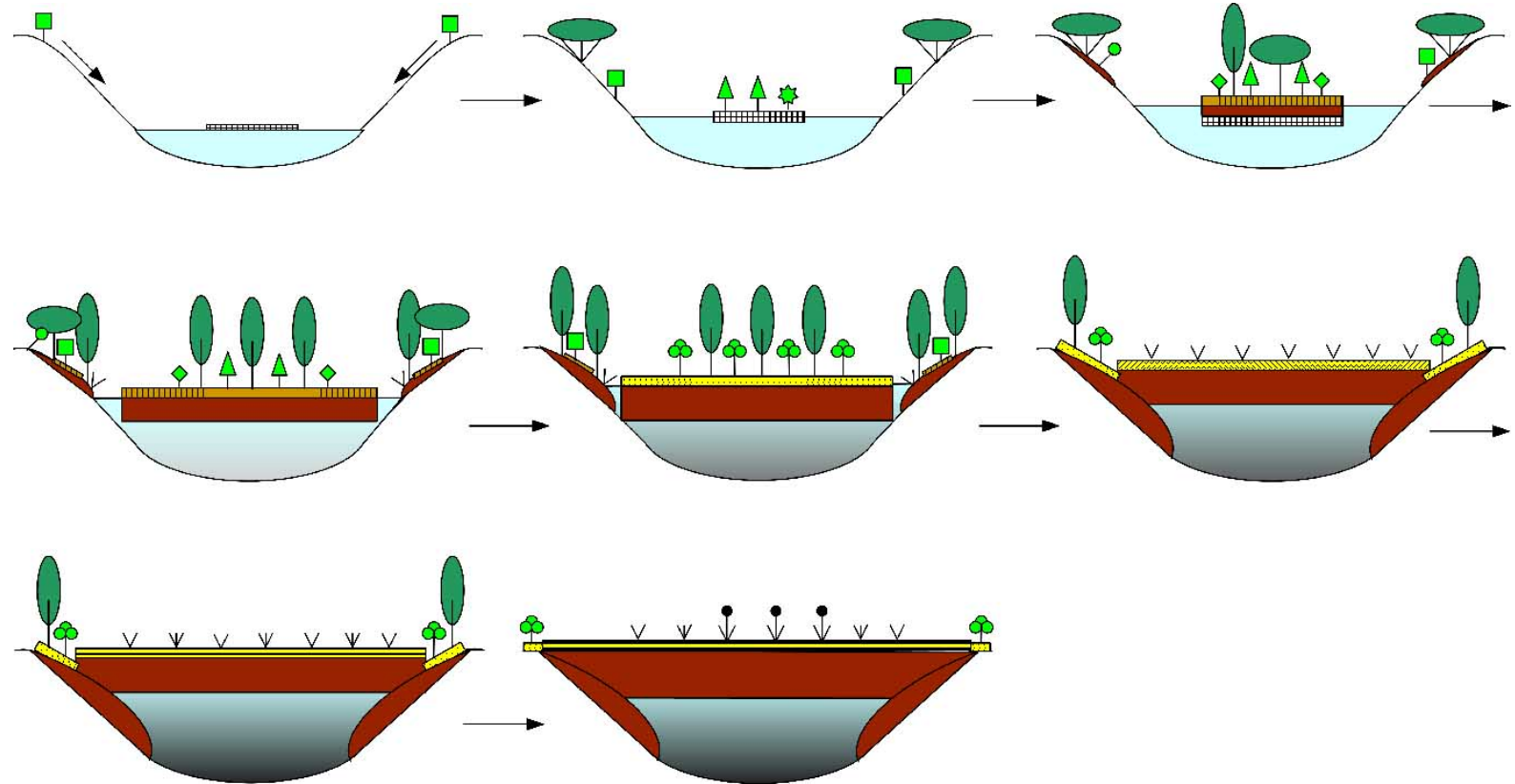

Fig. (3). Paludification of deep and wide karst depressions with high but gently sloping side walls and a large amount of water (the explanations - see the text).

birch in the tree layer and the establishment of the birchsphagnum eutrophic community.

Mire Lipki. The structure of the peat deposits means that the peat float passed the eutrophic stage of development (with willow, birch, Menyanthes trifoliata, Carex vesicaria, Phragmites australis, Equisetum sp.). The vertical growth of peat changed the hydrologic features of the float and provided conditions for the invasion of oligotrophic species of Sphagnum. The abundance of Betula pubescens and Menyanthes trifoliata decreased, whereas Oxycoccus palustris, Carex rostrata, Rhynchospora alba increased. These new communities formed mesotrophic peats (sphagnum, cottongrass-sphagnum and herbal-sphagnum), that form the modern surface peat. Therefore, this mire is characterized by the change of vegetation from eutrophic to mesotrophic types and the formation of the fifth stage of development of float.

Mire Bol'shoye. The oligothrophic vegetation and structure of peat deposits of the float means that the mire passed through previous stages of float development and is now characterized by the last stage (Fig. 2).

The analyses of vegetation and peat deposits of these karst mires resulted in some ideas about the stages of development of peat float (Fig. 2). The first stage forms by fallen tree leaves. This substrate is then inhabited by green mosses and "pioneer" herbs (Anthyrium filix-femina, Impatiens noli-tangere). Increasing thickness of the float (1$1.5 \mathrm{~m}$ ) provides for the growth of other herbs (Menyanthes trifoliata, Calla palustris, Comarum palustris, Scirpus sylvaticus), shrubs (Salix cinerea) and trees. Alder begins to grow in more wet and nutrient rich conditions, and birch invades later. Sometimes these tree species may grow together, however the vertical growth of the peat means that it becomes more dependent on nutrient-poor rain water rather than nutrient-rich lake water, and this decreases the nutrition of the root layer. This is the reason for the death of alder and the domination of birch, which is more typical in nutrient poor conditions. When the float becomes more than $2 \mathrm{~m}$. thick and its top layers begin to use rain water, sphagnum mosses begin to grow (Sphagnum squarrosum, $S$. riparia, $S$. centrale). Increasing float thickness and decreasing nutrition of the water result in the change of vegetation: meso- and oligotrophic species of Sphagnum $(S$. fallax, S. angustifolium, S. magellanicum), Carex rostrata, C. lasiocarpa, Rhynchospora alba and Eriophorum vaginatum begin to grow.

Peat formation begins from dead vegetative material (leaves, etc.) floating on the water's surface in the center of the lake or pond. The peat grows laterally from the center of the depression to its side walls, which are steeply sloping, and the thickness of the peat increases also. However, the peat is floating, and therefore it normally has a thickness of not more than 2-3 meters, because the lowest layer of the peat usually breaks off and sinks down to the bottom of the lake. During this time, the vegetation may change from eutrophic to meso- and oligotrophic types.

Based on the data given above, and on data about other mires not discussed here, the succession of vegetation may be shown as follows: fallen leaves on water's surface $\Rightarrow$ Athyrium filix-femina+Impatiens noli-tangere $\Rightarrow$ Alnus glutinosa-Athyrium filix-femina+Thelypteris palustris $\Rightarrow$ Betula alba+Alnus glutinosa-Athyrium filixfemina+Thelypteris palustris $\Rightarrow$ Betula alba- Thelypteris palustris $\Rightarrow$ Betula alba-Menyanthes trifoliata-Sphagnum squarrosum $\Rightarrow$ Carex rostrata + C. lasiocarpa-Sphagnum fallax $\Rightarrow$ Rhynchospora alba+Carex rostrata-Sphagnum magellanicum + S. angustifolium $\Rightarrow$ Eriophorum vaginatumSphagnum magellanicum.

Therefore, peat growth and increasing float thickness result in separation of the lower layer of the float, which sinks down to the floor of the depression. Sometimes, however, after this lower layer separates it remains suspended in the water above 
the floor. Permanent separation of the lower layer is the reason that the maximum thickness of the float is only $2.5-3 \mathrm{~m}$. The top of the float is on the water surface, whereas the lower parts are submerged in the water.

The formation of the peat float coincides with a rising water level in the karst depression, due to surface and ground waters flowing together. In this case, the level of the float in the depression will also rise. During different seasons the water level is different: usually it is higher in spring and fall and lower in summer [21]. The level of the float changes also. In general, depressions maintain both flowing surface water and ground water (of course, some part of the water evaporates), and every year the depressions have a greater volume of water than before. This means that every year the float level will be higher.

Paludification of deep and wide karst depressions with gently sloping sidewalls occurs by a combination of two ways. Mire Glavnoye is a good example. Analysis of the structure of the peat deposits in different parts of the mire resulted in the discovery of paludification depending on location: on the slopes of the depression, and in its central part. Paludification of the gently sloping sidewalls of the depression began from the formation of communities with trees (willow, birch), sedges (Carex rostrata, C. cinerea), some herbs (Calla palustris, Menyanthes trifoliata, Phragmites australis, Calamagrostis sp.) and Sphagnum mosses (less 20\%). Accumulation of water in the depression resulted in the decrease of the trees portion and an increase in the abundance herbs and sphagnum mosses (Sphagnum centrale, $S$. squarrosum, S. fimbriatum).

At the same time, on the water surface in the central part of the depression, float began to form. The stages of development were the same as with previously discussed floating mires, and the vegetation changed from eutrophic to mesotrophic types. The accumulation of surface and ground waters produced a rising higher water level in the depression, which in turn resulted in both the rising of the level of the float and the covering of previously produced peat deposit on the sidewall slopes. The rising water caused parts of this previous deposit to become disturbed, and their top parts began to rise to the surface of the water.

\section{CONCLUSIONS}

Karst depressions have wide distribution in European Russia. It depends on dissolution of limestone or gypsum in bedrock. Some depressions are going to paludificate by different ways, what is depending on water volume. Formation float mires is possible by different ways and correlates with strong filling up of depressions. One way, which was described here, is a good example of decidious forest influences on paludification of karst ponds because fallen leaves of broad-leaf trees form "first substrate" on water surface for invasion of plants. This peat is growing vertically but lowest layer of the peat breaks and goes down. It is a "top down" way of peat formation. The peat deposits of these mires consist from float and breaking off parts which are sinking to the bottom.

Sometimes the karst depression has combinative ways of paludification and their deposits have two separated parts of peat with different genesis. It means that float karst mires have different structure of peat deposits that depends on hydrological regime of the area.

\section{REFERENCES}

[1] Ameka GK, de Graft-Johnson KA. The Sudd Vegetation of Weija Lake, Ghana. Kirkia 1998; 17(1): 1-9.

[2] Boughey AS. The explosive development of floating weed vegetation on lake Kariba. Adansonia 1963; 3(1): 49-61.

[3] Cook CD, Gut BJ. Salvinia in the State of Kerala, India. Proc Natl Acad Sci USA 1971; 17(4): 438-47.

[4] Crum HA. A focus on peatlands and peat mosses. Ann Arbor: University of Michigan Press 1988.

[5] Shaw PJ. A. Orchid woods and floating islands. The ecology of fly ash. Bri Widl 1994; 5(3): 149-57.

[6] Tyler PA. Lagoon of Islands. Tasmania deaths knell for a unique ecosystem? Biol Conserv 1976; 9: 1-11.

[7] Gaudig G, Couwenberg J, Joosten H. Peat accumulation in kettle holes: bottom up or top down? Mires and Peat 2006; 1(6): 1-16. Available from: http://www.mires-and-peat.net/

[8] Andreas BK, Bryan GR. The vegetation of three Sphagnumdominated basin-type bogs in northern Ohio. Ohio J Sci, 1990; 90: 54-66.

[9] Booth RK, Jackson ST, Gray CE. Paleoecology and high-resolution paleohydrology of a kettle peatland in upper Michigan. Quat Int 2004; 611: 1-13.

[10] Casparie WA. Bog development in south-eastern Drenthe. J Veg Sci 1972; 25: 1-271.

[11] Lynn LM. The vegetation of Little Cedar Bog. Southern New York: Bull Torrey Bot Club 1984; vol. 111: pp. 90-95.

[12] Hulme PD, Shirriffs J. Pollen analysis of a radiocarbon-dated core from North Mains, Strathallan, Perthshire. Proc Soc Antiq Scot 1995; 115: 105-13.

[13] McGlone MS, Moar NT, Meurk CD. Growth and vegetation history of alpine mires on the old man range, central otago. New Zealand. ct. Antarct Alp Res 1997; 29-1: 32-44.

[14] Mouser PJ, Hession WC, Rizzo DM, Gotelli NJ. Hydrology and Geostatistics of a Vermont, USA Kettlehole Peatland. J Hydrol 2005; 301: 250-66.

[15] Chikishev AG. Karst of Russian Hills. Moscow: Moscow University Press 1978 .

[16] Volkova E, Burova O, Visloguzova D. The principles of apportionment of mire areas in the Tula Oblast. Nat Tech Sci 2003; 4: 34-8.

[17] Volkova EM. The mires of museum-reserve Yasnaya Polyana: genesis and modern state. Biol Divers Tula Region 2004; 4: 54-76.

[18] Volkova EM. The features of paludification processes on north-east of Srednerusskaya Hills. Proceedings of XII congress of Russian botanical society and Russian conference. Fundamental problems of botany at the beginning of XXI century. Petrozavodsk 2008: pp. 49-51.

[19] Volkova EM, Burdykina ES. Origin, development, and current status of karst mires near v. Kochaki (Schekino Rayon, Tula Oblast). Nat Tula Oblast 2007; 1: 88-105.

[20] Turemnov SN. Atlas of plant remains in peat. Moscow: MoscowLeningrad 1959.

[21] Visloguzova DV. The seasonal dynamics of water table in karst wetlands near the settlement Ozyorny (Tula Area). Nat Tula Region 2007; 1: 3-9. 